\title{
The Enlightenment to School Education of Positive Energy Obtained from the Principle of Performance
}

\author{
Sun Hao \\ Department of physical education in Kunming university of science and technology \\ Kunming,China \\ 471563075@qq.com
}

\begin{abstract}
As the founder of American psychology, William James puts forward the great psychological principle of "performance". Richard Wiseman associated principle of performance closely to positive energy to reveal that people's behavioral patterns can affect their beliefs, emotions, willpower. As a branch of psychology, education psychology can also obtains important enlightenment from the principle of "performance" so as to eliminate the negative energy in our school activities and increase the positive energy of our splendid life.
\end{abstract}

Keywords-principle of performance; positive energy; school education

\section{THE RELATIONSHIP BETWEEN "PERFORMANCE" PRINCIPLE AND EDUCATION PSYCHOLOGY}

Before the psychology becomes an independent science, some psychological problems about "heart", "consciousness", "life" has always been the ancient issues of common concern between philosophers and educators. As part of the psychology, education psychology is a discipline which discusses psychological problems among the education activities and it refers to the way teachers teach and students learn, as well as the knowledge and skills mastering and the formation of personality, etc. To study these rules helps the improvements of education qualities.

William James considers emotions as a result after people see the expression of their own, and emotions can be evolved instantaneously when brain observes body reactions, which is called as "principle of performance" by Richard Wiseman. Wiseman not only explains the great "principle of performance" but also breaks the beliefs like "character determines destiny" or "emotion decides behavior", etc. Meanwhile, he reveals what kind of behavior can affect people's beliefs, emotions and willpowers, and by means of series of training methods, our many inner positive energy such as confidence, open-mindedness, cheerfulness, which can avoid selfish, suspicion, frustration, depression and other negative energy. So it can eliminate negative factors in our school activities and leads us a wonderful life.

\section{THE ENLIGHTENMENT TO SCHOOL EDUCATION BETWEEN PRINCIPLE OF PERFORMANCE AND POSITIVE ENERGY}

\section{A Enlightenment to control your emotions}

Common sense tells us that people smiles because of happiness, and escape because of fearfulness, and cry because of sadness, as well as sweat because they are anxious. That is to say, emotions can influence our behaviors. However, "principle of performance" tells us that people will feel happy when they smile, and people will feel angry when they frown meanwhile negative emotions surround their hearts.

Happiness can be made. William James thinks that people smiling should feel more happier compared with people frown. In order to testify this theory, in the late 1960s, a young scholar named James laird had some volunteers in his lab and made them smile or frown then reported their emotions. For fear of their emotions influenced when they knew experiment subjects, laird found one way making people smile and frown fluently. When volunteers adjusted their expressions, a form was filled with the extent to anxiety, joy and regret. Experimental results were very significant. When volunteers smiled they would feel happy; when they frown they would feel angry for no reason at all at the same time negative emotions increased.

The most effective way to make one happy is sitting happily or looking, dancing, chatting around happily. A teacher we know whose students valuation at the top each semester. She speak softly and the atmosphere in her class is very easy, some students also clap when class is over. Teachers teach happily in the post, students enjoy and complete their studies efficiently; Teachers no longer need to mobilize students' enthusiasm, and students no longer need their parents' stick to move forward. So smile, laugh, and dispel negative emotions, to make happy mood stronger and stronger, energy more and more.

\section{$B$ Anger and anxiety can be dispelled}

Psychologist Brad seaman has made many experiments and can prove how to behave calmly to make a person stops anger quickly. He deliberately provokes the students by giving their homework bad review. Then he gives some of the students a pair of mittens each, and shows photo of the evaluation teacher, and makes the 
students hit sandbags while thinking about the person. Another group of students sit in the room quietly for two minutes. The result shows that the students hitting sandbags become more angrily while the moods of students sitting quietly gradually slows down.

The most effective way to eliminate anger is not to behave aggressively, but to behave calmly so as to solve problems with a fast and efficient methods. So corporal punishments to students' bad behavior is not adoptable, which only make teachers become more and more angry, students more and more anxiety. Don't let negative emotions inflate, instead calm mind as soon as possible and stimulate positive energy.

\section{The enlightenment to willpower}

Some researchers of national university in Singapore recruits a few groups of participants, one group with their hands into the ice buckets as long as possible, another group with a kind of vinegar drunk which tastes bad, third group to buy healthy food instead of the dessert. Each time half of the participants are asked to tighten some muscles or clench the fists or sit with the the heels raising. Participants behaves as if they are trying to control themselves. The results prove that participants who do the above exercise will hand into the ice bucket for a longer time, drink more of the vinegar, or buy healthier food.

Students should try to tighten some muscles in our body, for example, when wandering in class you can with your hands behind your back, spine straight; when in trouble, with your fingers holding a pencil; taking part in physical exercises especially long-distance running, with your teethes gritted. Change an action of the body, you will have more stamina and full of positive energy, become stronger and more dynamic.

\section{$D$ The enlightenment to interpersonal relationship and confidence}

In the early 1970s, many schools in Austin city of the United States had abolished racial segregation. Unfortunately, students of different races harboured the deep suspicions and hatreds. Psychologist Elliot aronson in the university of Texas created a new method-"jigsaw puzzle". He devided five to six his students into a team, ensured each group of students with different genders, races, as well as abilities. Then course contents were divided into several parts, each students only needed to learn one part of it. Over a period of time, after they got information and knowledge, new groups arranged again and the students learning the same contents previously sat together and discussed what they had learned. After the discussion students came back to their original group and show show their own learning to the students of the group. As a result, they soon eliminated the prejudice against each other and became more willing to get along with each other, meanwhile their self-confidences were augmented.

Some of our class teachers often complains about the class which is difficult to manage, disunity between students. Why not use "jigsaw puzzle", to make us work together to do something a person can't do. In the process let them realize the power of solidarity and collaboration, trust each other, and experiences self-confidence after the success. Additionally, using this methods can improve students' learning enthusiasm, decrease truancy rates significantly, raise students' learning and self-confidence.

\section{E The enlightenment to control thinking}

Prisoners were released after the Korean war ended, among which 21 American soldiers decided to continue to stay in there and defamed their own country publicly. Surprisingly, a lot of captured personnels of the United States begun to advocate the superiority of North Korea after their returning to the hometown. What changed their beliefs? Some people said the north Korean side used flash lights and white noises to wash their brains, while others thought that north Korea side used some advanced hallucinogenic drugs and broadcast "Socialism is good for them" every day.

Researchers Larry weber and his colleagues in Tulane university conducted a two-year, large-scale trial survey which involving thousands of students of 36 schools across the United States. Its aim was whether physical activity could promote to lose weight in high school. The researchers in parts of the schools advertised the importance of physical activities and encouraged their participating in sports fitness clubs. While the others schools as the control group didn't do any propaganda, mobilization and counseling to their students. The results were of no avails. Compared with the reference groups, the students who were encouraged to take part in physical exercise and had more opportunities to do more physical exercises were not different in the average weight parameters. The facts revealed that it was not obvious by means of changing thinking styles aiming to change humans activities. Like the government was always advertising "smoking is harmful to health", but how many smokers abandoned smoking?

So what on earth changed American solders' beliefs? That is the "principle of performance". Guards would shake hands with prisoners friendly when they entered the detention camps. Within weeks the prisoners had to learn for a long time and discussed when their class was over to make sure their "right" conclusions. Soon, the prisoners begun to copy simple anti-war rhetoric, a bonus like soap or cigarettes could be acquired when they did well. After a few weeks, guards begun to raise the stakes for prisoners and asked them to read the remarks loudly. In addition, if the prisoner volunteered to write articles for the detention camps and behaved friendly, they could get fruits or sweets, even a medal, not doing those trivial daily works. As time passed, many prisoners were willing to believe that anti-war rhetoric and agreed with these views.

The same methods can affect the students also. Again and again singing the national anthem can promote their patriotism; Repeatedly reading some brief slogans like "life lies in movement", "i will keep healthy if i keep moving", their participation enthusiasm of exercise can be 
ignited. When some student speaks little words in class, the teacher also don't criticize them, instead let him say a few times: "I can do it very attentively." Let people's talking becomes into their faiths. As a century ago, William James had said: "if you want to have a quality, act as if you already have it." William James in his book "Talking about psychology with teachers" had said that:"i can't deny the fact

that if you take students as an organism who have feelings, actions, reactions, associations, with part of them imposed and part of them unrestrained. Then you can have a clear look of them. Now consider them a delicate machine. Moreover, if you treat and love them under the concept of goodness, then you are confident to become a good teacher. We can acquire happiness from smile, we can obtain willpower from muscle contraction, we can have strength and confidence from "jigsaw puzzle", also can we change our minds by means of demonstrating our convictions repeatedly. In a word, our emotions, thinking styles and personalities can be changed. Let's constantly gather positive energy and create a whole new life!

\section{REFERENCES}

[1] BAIDU ENCYCLOPEDIA. WILLIAM JAMES. HTTP://BAIKE.BAIDU.COM/VIEW/357412.HTM

[2] [British] Richard Wiseman (Richard Wiseman). The positive energy [M]. Li lei, eds. Hunan: hunan literature and art publishing house. 2012

[3] baidu encyclopedia. Richard wiseman. http://baike.baidu.com/view/2358411.htm

[4] li hui. The psychology principle and application [M]. Yunnan, yunnan education press. 1996 